\title{
Impact of Training on Employee Performance in the context of Telecommunication sector of D. G. Khan, (Pakistan)
}

\author{
Nadeem Iqbal $^{1}$, Naveed Ahmad ${ }^{2, *}$, Komal Javaid ${ }^{1}$ \\ ${ }^{1}$ Faculty of Management Sciences, Baha Uddin Zakariya University, Multan, Pakistan \\ ${ }^{2}$ Faculty of Management Sciences, Indus International Institute, D. G. Khan, Pakistan \\ *E-mail address: naveeddgk2010@gmail.com
}

\begin{abstract}
This paper examines the relationship between training and its impact on employees performance in the context of "Telecommunication Sector of D. G. Khan" Pakistan. There are three hypotheses and three objectives of this research study and by using a questionnaire 150 employees were chosen for data collection from telecommunication. "ANOVA and SPSS" Correlation coefficient was used for data analysis. Independent variable of this study is Training and dependent variable is employee performance. The independent variable training has two determinants salary and job involvement. Results showed Positive relationships between Training, Salary and Job Involvement with Employee Performance.
\end{abstract}

Keywords: Training; Employee Performance; Salary; Job Involvement

\section{INTRODUCTION}

Human resource has deliberate means to improve the supportable modest returns in this era of the globalization. One important role of the Human Resource Management (HRM) is active usage of human resources is training and development. Active training is an outlay in human resources of an association, with the mutually instant and long-term profits. Training is basic component for enhancing performance; that can raise the level of individual and executive capability. By using the knowledge, workers will narrow the gap and capable to accomplish further responsibilities in a smaller time period and improve their efficiency. Training is the device to fill gap and the organizations must practice it intelligently to increase employee efficiency.

Modern studies disclose that training facilitates furthermost establishment and encounters their aims and purposes. Thus in this respect workers are capable to study different work ideas, restore their abilities, increase their work assertiveness and increase efficiency (Cole 2002). The main role of training is to increase workers' ability for present and forthcoming obligations and accountabilities. Each mode, applicability and excellence needs to be supported hence that the worker can raise the job inspirational belongings (Mullins 2003). In conflicts, training supports them to alter by characteristics like knowledge and rivalry (Dessler 2000). A coordination platform is the organized procedure that permits corporations to want new workers; clarify the operational rules, prospects, precise abilities 
and awareness of the workers (Sims, 2001, p. 34). Thomas (1997) says that the worker training contains instruction workers abilities which can support them to become extra capable and fruitful employees. Thus, training attains an intentional worth for inns as facility worth be determined through on worker client attention efficiency Connie Zheng (2009). A training platform is a fundamental human principal growth job where it emphases on rising total worker capabilities to overawed their everyday work difficulties, and that can lead to the sophisticated structural growth and growth in the prospect (DeSimone, Warner \& Harris, 2002; MacNeil, 2004). The uppermost administration then recognize the training necessities and mention specific categories of the training program to overwhelmed such worker insufficiencies (Pfeffer, 1998; Rodrígues \& Gregory, 2005).

\section{1. Objectives}

The foremost objective of this study is to make a model in between Training, Salary, Job Involvement and Employee Performance. There are three further objectives of this research included:

1) To determine the impact of training on employee performance.

2) To determine the impact of salary on employee performance.

3) To determine the impact of job involvement on employee performance.

\section{2. Research Questions}

1) What is the relationship between training and employee performance?

2) What is the relationship between salaries and employee performance?

3) What is the relationship between job involvements and employee performance?

The significance purpose of Human Resource Management is the active usage of human capitals in training and development. Practically everybody currently identifies the significance of training on the achievement and progress of the establishments. Workers are very essential and exclusive resource to all association. There are the significant variations now in relations of the importance of the worker. Training is thus essential to improve the awareness, abilities and assertiveness of the workers. That will also create opportunity for workers to obtain additional information based on the training and additional result alterations in further associate.

\section{LITERATURE REVIEW}

\section{1. Training}

Trainings at the exertion are usually duty or work adjusted (Bach and Sisson 2000). Establishments which arrange training must been recognized to achieve sophisticated job performance. (Law and Kelton 1991) Training links the gap of the exertion presentation vs. the exertion objectives achievement (Cook and Wall 1980, p. 39-52). Training will empower the employees to meet sophisticated abilities for performing qualified assistances such as the workers struggle to increase greater characters with greater advantage (McManus, et al 2004). Training indicates to the extraordinary performance, respectable headship and bottomless employee commitment (Accenture \& SAP 2004). Here is indication that the present era recognizes a growth in the workstation training's wants for the establishments of profitable reserves (Van Buren \& Erskine 2002). 
Though, the earlier research has specified trouble in recognizing destiny among the training and executive performance (Tan and Batra, 1994; Blundell et al., 1999). A recognized training platform is a determination through the manager to offer chances on behalf of the worker to attain job-related abilities, assertiveness and awareness, McGhee et al (1996:55).

\section{2. Determinants of Training based on Literature}

There are two determinants of Training based on litrature

1) Salary

2) Job Involvement

The explanation of these two terms is given below:

\section{1) Salary}

Salary or pay is the practice of periodic payment from the firm to its employee, which is absolutely specified in an occupation agreement. Remuneration, salary or pay is deliberated an important payment to influence the employees and their performance to the objectives of establishment (Oshagbemi, 2000). Salary fill-ups have not been steadily appraised via tough procedures of the performance (Kober and Van Damme, 2006; Mtonya, Mwapasa, and Kadzandira, 2005). Chopra et al. (2008) originate no studies inspecting salary alterations and performance of the work, or exploratory salary rises and preservation of the strength employees. China has originated trialling with the salary modifications in the previous years; these have been frequently concentrated on salary for the performance and decreasing charges, with no starting point or regulator/judgement clusters (Yip et al., 2010). The main paper deliberated (Israr et al., 2000) collected emotional descriptions around the injurious effects of organizational alteration packages on salary practicality, comprising the requirement for double contracts (perhaps in the familiar segment, Tanga et al., 2001), illegal expenditures and additional 'counterproductive' exertion actions by the municipal retainer employees (for a further over-all case, see Kyaddondo and Whyte, 2003; for previous readings lacking salary deviation, see McPake et al., 1999; Munene, 1995).

\section{2) Job Involvement}

Job involvement is trustily and incidentally pretentious through these variables and the performance is spontaneously precious through job involvement (Brown and Leigh, 1996). Job involvement effects in the sophisticated stages of the in-role job presentation through definitely distressing workers ${ }^{\text {ee }}$ inspiration and struggle (Brown, 1996). However certain examiners stress on awareness that the job involvement increases the performance then to certain magnitude merely (Cron 1984; Dubinsky and Hartley, 1986), Brown and Leigh, 1996). Permitting to the Mowday, Steers and Porter, (1982) job involvement is the comparative power which differs after first to the other in the diverse organizations. In- part job performance states to accomplishments which are associated to the workers' prescribed character necessities (Borman \& Motowidlo, 1997). For example Brown and Leigh (1996) in their learning originate that the job involvement took together straight and incidental belongings via struggle on the performance. Job involvement is the gradation to which a specific recognizes the expressively by the work and deliberates his or her supposed level of performance significant to the self-respect (Blau and Boal, 1987). 


\section{3. Employee Performance}

Performance can be clear such as the attainment of the quantified job restrained alongside determined or recognized principles of the accurateness, comprehensiveness, price and speediness. Kenney et al., (1992) identified that the worker's performance is dignified in contradiction of performance criterions established in the association. Competence and efficacy are constituents of the performance distant from the effectiveness and efficiency and training is the manner of growing person's performance (Cooke, 2000). Performance is concluded which executives certify that worker actions and productions are corresponding with the establishment's objectives (Noe et al, 2006). Armstrong (2000 cited in Kagari et al, 2010) formal association performance is a worth of receiving improved consequences from the entire association or groups or persons in it, through accepting and handling performance in an established background of strategic objectives, principles and proficiency necessities. Lewis (1998 cited in Harzing, 2004) performance organization is a word recycled to define a combined set of procedures which require an autonomous presence under the specific terms. Bernthal (1996 cited in Harzing, 2004) distribute performance includes: (1) relatives to the managerial policy (2) set separate performance objectives (3) given that consistent response on improvement to those objectives (4) given that chances for cultivating (5) Involving consequences and prizes Furthermore, worker performance can clear as spiritual agreement (Stiles et al, 1997 cited in Harzing, 2004).

\section{4. Hypotheses}

There are two types of hypotheses

Hypotheses 1: There is Positive relationship of training on employee performance.

Hypotheses 2: There is Positive relationship of salaries on employee performance.

Hypotheses 3: There is Positive relationship of job involvements on employee performance.

H1

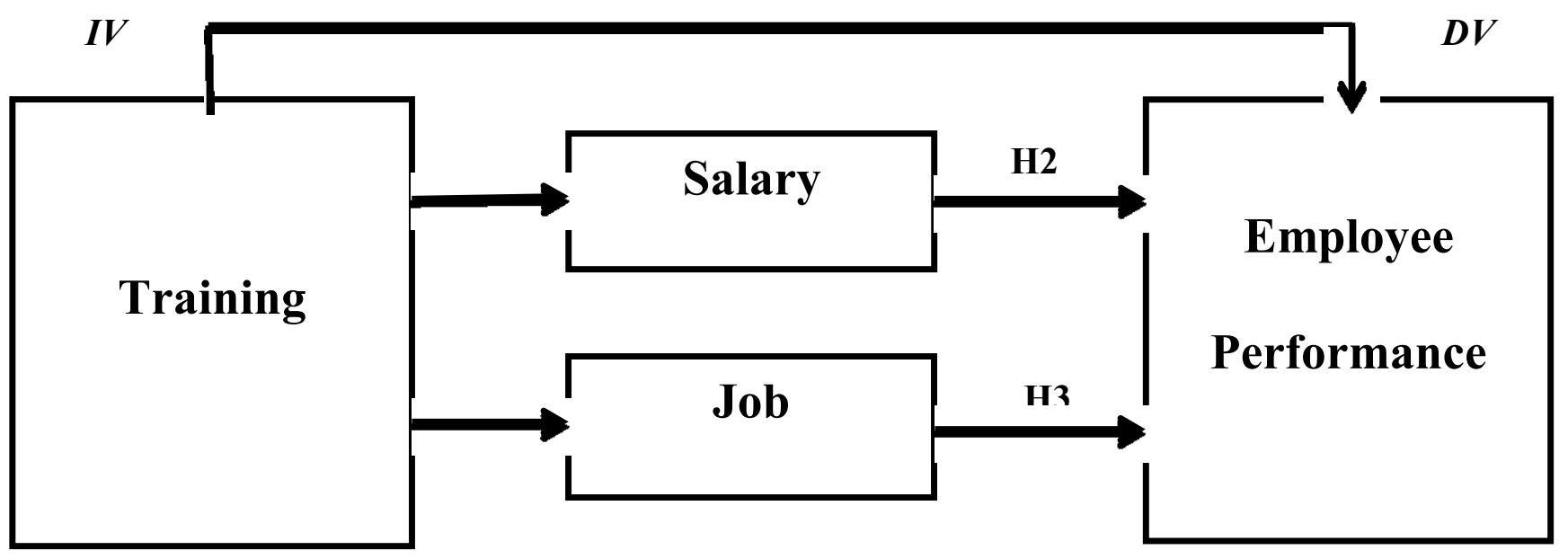

Figure 1. Conceptual Framework. 


\section{RESEARCH METHOD}

\section{Sample}

In this research first of all author(s) have designate training has direct relationship with the employee performance conferring to the pronounced literature and determinants of training are; salary, job involvement also have the direct association with the employee performance.

\section{1. Research design}

Various authors designate diverse difficulties proximate the vigorous variables of research through the descriptive research or design.

The persistence is to gather comprehensive and accurate clue which defines a modern prevalence. This descriptive research is agreed in which telecommunication sector is employed as the population.

\section{2. Target population}

In this research target population is the staff of the telecommunication sector of D.G.Khan. The explanatory occupants are transitory in the Table 1 to Table 5.

\section{3. Sampling design}

This discussion describes the population such as simple random sampling which supports all factors in the population and correspondent coincidental for the collection. 150 respondents were designated which illustrate population for this research study. The crucial indications for this study are turn into low-priced and rate operative.

\section{4. Data collection}

Response is very major indication congregation device. The reviews stayed organized to gather quantifiable proofs. Indications must been collected through the belongings of a typical questionnaire that encompasses thorough questions (gender, age and level of education). Likert scale fifth range from $1=$ strongly disagree to $5=$ strongly agree is used in this research study.

\section{5. Data analysis}

Data analysis comprehend the imperious varieties and interactions of the variables to mark simpler them by way of the decided ways of the performance and the whole degrees. The descriptive research was employed. Permitting to the delivery of expectedness indications was composed the statement the philosophies of variables and actions in associations of the happening.

To discover out the validity of the review we appraise the hypotheses, by using the regression and correlation analysis. To revise the numerical indications SPSS software is used for valuation. The structures of the validity of investigation are accepted above principles. The reliability of analysis is proficient through the sample compelling 150 respondents of employees of telecommunication sector of D. G. Khan (Pakistan). 
Table 1. Frequency.

\begin{tabular}{|c|c|c|c|c|}
\hline \multicolumn{5}{|c|}{ Statistics } \\
\hline \multicolumn{2}{|c|}{} & GENDER & AGE & LOE \\
\hline \multirow{2}{*}{$\mathrm{N}$} & Valid & 150 & 150 & 150 \\
\cline { 2 - 6 } & Missing & 0 & 0 & 0 \\
\hline \multicolumn{2}{|c|}{ Mean } & 1.2667 & 1.9333 & 2.2667 \\
\hline
\end{tabular}

Table 2. Gender.

\begin{tabular}{|c|c|c|c|c|c|}
\hline \multicolumn{2}{|c|}{} & Frequency & Percent & $\begin{array}{c}\text { Valid } \\
\text { Percent }\end{array}$ & $\begin{array}{c}\text { Cumulative } \\
\text { Percent }\end{array}$ \\
\hline \multirow{4}{*}{ Valid } & 1.00 & 110 & 73.3 & 73.3 & 73.3 \\
\cline { 2 - 6 } & 2.00 & 40 & 26.7 & 26.7 & 100.0 \\
\cline { 2 - 6 } & Total & 150 & 100.0 & 100.0 & \\
\hline
\end{tabular}

Table 3. Age.

\begin{tabular}{|c|c|c|c|c|c|}
\hline \multicolumn{2}{|c|}{} & Frequency & Percent & Valid Percent & $\begin{array}{c}\text { Cumulative } \\
\text { Percent }\end{array}$ \\
\hline \multirow{3}{*}{ Valid } & 1.00 & 40 & 26.7 & 26.7 & 26.7 \\
\cline { 2 - 6 } & 2.00 & 80 & 53.3 & 53.3 & 80.0 \\
\cline { 2 - 6 } & 3.00 & 30 & 20.0 & 20.0 & 100.0 \\
\cline { 2 - 6 } & Total & 150 & 100.0 & 100.0 & \\
\hline
\end{tabular}


Table 4. Education.

\begin{tabular}{|c|c|c|c|c|c|}
\hline \multicolumn{6}{|c|}{ LOE } \\
\hline & & Frequency & Percent & $\begin{array}{c}\text { Valid } \\
\text { Percent }\end{array}$ & $\begin{array}{c}\text { Cumulative } \\
\text { Percent }\end{array}$ \\
\hline \multirow{4}{*}{ Valid } & 1.00 & 36 & 24.0 & 24.0 & 24.0 \\
\hline & 2.00 & 38 & 25.3 & 25.3 & 49.3 \\
\hline & 3.00 & 76 & 50.7 & 50.7 & 100.0 \\
\hline & Total & 150 & 100.0 & 100.0 & \\
\hline
\end{tabular}

Table 5. Descriptive Statistics.

\begin{tabular}{|c|c|c|c|}
\hline & Mean & Std. Deviation & $\mathrm{N}$ \\
\hline Training & 1.1089 & .25833 & 150 \\
\hline Salary & 1.0911 & .25441 & 150 \\
\hline Involvement & 1.1089 & .23727 & 150 \\
\hline Performance & 1.1133 & .24065 & 150 \\
\hline
\end{tabular}

Table 6. Correlations.

\begin{tabular}{|c|c|c|c|c|c|}
\hline \multicolumn{2}{|c|}{} & Training & Salary & Involvement & Performance \\
\hline \multirow{4}{*}{ Training } & Pearson Correlation & 1 & $.875^{* *}$ & $.833^{* *}$ & $.889^{* *}$ \\
\cline { 2 - 6 } & Sig. (2-tailed) & & .000 & .000 & .000 \\
\cline { 2 - 6 } & $\mathrm{N}$ & 150 & 150 & 150 & 150 \\
\hline \multirow{4}{*}{ Salary } & Pearson Correlation & $.875^{* *}$ & 1 & $.888^{* *}$ & $.905^{* *}$ \\
\cline { 2 - 6 } & Sig. (2-tailed) & .000 & & .000 & .000 \\
\cline { 2 - 6 } & & 150 & 150 & 150 & 150 \\
\hline
\end{tabular}




\begin{tabular}{|l|c|c|c|c|c|}
\hline \multirow{3}{*}{ Involvement } & Pearson Correlation & $.833^{* *}$ & $.888^{* *}$ & 1 & $.834^{* *}$ \\
\cline { 2 - 6 } & Sig. (2-tailed) & .000 & .000 & & .000 \\
\cline { 2 - 6 } & $\mathrm{N}$ & 150 & 150 & 150 & 150 \\
\hline \multirow{3}{*}{ Performance } & Pearson Correlation & $.889^{* *}$ & $.905^{* *}$ & $.834^{* *}$ & 1 \\
\cline { 2 - 6 } & Sig. (2-tailed) & .000 & .000 & .000 & \\
\cline { 2 - 6 } & $\mathrm{N}$ & 150 & 150 & 150 & 150 \\
\hline \multirow{2}{*}{$* *$ Correlation is significant at the 0.01 level (2-tailed). }
\end{tabular}

Table 7. Regression: Hypotheses 1. Model Summary

\begin{tabular}{|c|c|c|c|c|}
\hline Model & $\mathrm{R}$ & $\mathrm{R}$ Square & $\begin{array}{c}\text { Adjusted R } \\
\text { Square }\end{array}$ & $\begin{array}{c}\text { Std. Error of the } \\
\text { Estimate }\end{array}$ \\
\hline 1 & $.889^{\mathrm{a}}$ & .790 & .788 & .11070 \\
\hline
\end{tabular}

Table 8. ANOVA results.

\begin{tabular}{|c|c|c|c|c|c|c|}
\hline \multicolumn{7}{|c|}{ ANOVA $^{\mathrm{a}}$} \\
\hline & Model & $\begin{array}{l}\text { Sum of } \\
\text { Squares }\end{array}$ & $\mathrm{df}$ & $\begin{array}{l}\text { Mean } \\
\text { Square }\end{array}$ & $\mathrm{F}$ & Sig. \\
\hline \multirow{3}{*}{1} & Regression & 6.815 & 1 & 6.815 & 556.177 & $.000^{\mathrm{b}}$ \\
\hline & Residual & 1.814 & 148 & .012 & & \\
\hline & Total & 8.629 & 149 & & & \\
\hline \multicolumn{7}{|c|}{ a. Dependent Variable: Performance } \\
\hline
\end{tabular}


Table 9. Coefficients ${ }^{\mathrm{a}}$.

\begin{tabular}{|c|c|c|c|c|c|c|}
\hline \multirow{2}{*}{\multicolumn{2}{|c|}{ Model }} & \multicolumn{2}{|c|}{$\begin{array}{l}\text { Unstandardized } \\
\text { Coefficients }\end{array}$} & \multirow{2}{*}{$\begin{array}{c}\text { Standardized } \\
\text { Coefficients } \\
\text { Beta }\end{array}$} & \multirow[t]{2}{*}{$\mathrm{T}$} & \multirow[t]{2}{*}{ Sig. } \\
\hline & & B & Std. Error & & & \\
\hline \multirow[t]{2}{*}{1} & (Constant) & .195 & .040 & & 4.887 & .000 \\
\hline & Training & .828 & .035 & .889 & 23.583 & .000 \\
\hline
\end{tabular}

a. Dependent Variable: Performance

Table 10. Regression: Hypotheses 2.

Model Summary

\begin{tabular}{|l|c|c|c|c|}
\hline Model & $\mathrm{R}$ & $\begin{array}{c}\mathrm{R} \\
\text { Square }\end{array}$ & $\begin{array}{c}\text { Adjusted R } \\
\text { Square }\end{array}$ & $\begin{array}{c}\text { Std. Error } \\
\text { of the } \\
\text { Estimate }\end{array}$ \\
\hline 1 & $.905^{\mathrm{a}}$ & .819 & .818 & .10266 \\
\hline
\end{tabular}

Table 11. ANOVA

\begin{tabular}{|l|c|c|c|c|c|c|}
\hline \multicolumn{2}{|c|}{ Model } & $\begin{array}{c}\text { Sum of } \\
\text { Squares }\end{array}$ & df & $\begin{array}{c}\text { Mean } \\
\text { Square }\end{array}$ & F & Sig. \\
\hline \multirow{2}{*}{$1 \quad$ Regression } & 7.069 & 1 & 7.069 & $\begin{array}{c}670.76 \\
2\end{array}$ & $.000^{\mathrm{b}}$ \\
\cline { 2 - 7 } & Residual & 1.560 & 148 & .011 & & \\
\cline { 2 - 7 } & Total & 8.629 & 149 & & & \\
\hline
\end{tabular}


Table 12. Coefficients ${ }^{\mathrm{a}}$.

\begin{tabular}{|c|c|c|c|c|c|c|}
\hline \multirow{2}{*}{\multicolumn{2}{|c|}{ Model }} & \multicolumn{2}{|c|}{$\begin{array}{l}\text { Unstandardized } \\
\text { Coefficients }\end{array}$} & \multirow{2}{*}{$\begin{array}{c}\text { Standardized } \\
\text { Coefficients } \\
\text { Beta }\end{array}$} & \multirow[t]{2}{*}{$\mathrm{T}$} & \multirow[t]{2}{*}{ Sig. } \\
\hline & & B & Std. Error & & & \\
\hline \multirow[t]{2}{*}{1} & (Constant) & .179 & .037 & & 4.838 & .000 \\
\hline & Salary & .856 & .033 & .905 & 25.899 & .000 \\
\hline
\end{tabular}

a. Dependent Variable: Performance

Table 13. Regression: Hypotheses 3.

Model Summary

\begin{tabular}{|c|c|c|c|c|}
\hline Model & $\mathrm{R}$ & R Square & $\begin{array}{c}\text { Adjusted R } \\
\text { Square }\end{array}$ & $\begin{array}{c}\text { Std. Error of } \\
\text { the Estimate }\end{array}$ \\
\hline 1 & $.834^{\mathrm{a}}$ & .695 & .693 & .13332 \\
\hline \multicolumn{4}{|l}{} \\
a. Predictors: (Constant), Involvement
\end{tabular}

Table 14. ANOVA ${ }^{\mathrm{a}}$

\begin{tabular}{|c|c|c|c|c|c|c|}
\hline \multicolumn{2}{|c|}{ Model } & Sum of & df & Mean & $\mathrm{F}$ & Sig. \\
\hline \multirow[t]{3}{*}{1} & Regression & 5.998 & 1 & 5.998 & 337.488 & $.000^{\mathrm{b}}$ \\
\hline & Residual & 2.630 & 148 & .018 & & \\
\hline & Total & 8.629 & 149 & & & \\
\hline \multicolumn{7}{|c|}{ a. Dependent Variable: Performance } \\
\hline
\end{tabular}


Table 15. Coefficients ${ }^{\mathrm{a}}$.

\begin{tabular}{|c|c|c|c|c|c|c|}
\hline & \multirow[t]{2}{*}{ Model } & \multicolumn{2}{|c|}{$\begin{array}{l}\text { Unstandardized } \\
\text { Coefficients }\end{array}$} & \multirow{2}{*}{$\begin{array}{c}\text { Standardizd } \\
\text { Coefficients } \\
\text { Beta }\end{array}$} & \multirow[t]{2}{*}{$\mathrm{T}$} & \multirow[t]{2}{*}{ Sig. } \\
\hline & & B & Std. Error & & & \\
\hline \multirow[t]{2}{*}{1} & (Constant) & .176 & .052 & & 3.365 & .001 \\
\hline & Involvement & .846 & .046 & .834 & 18.371 & .000 \\
\hline
\end{tabular}

\section{SUMMARY}

Hypotheses 1: Correlation outcomes indicate that there was significant positive relationship between training and employee performance ( $\operatorname{sig}=.000 \mathrm{r}=.889^{* *}$ ). $\mathrm{R}$ is the multiple correlation coefficients, between the observed and predicted values of training the dependent variable employee performance. In the range of 0 to $1 \mathrm{r}$ value is significant.

Hypotheses 2: Correlation outcomes indicate that there was significant positive relationship between salary and employee performance $\left(\operatorname{sig}=.000 \mathrm{r}=.905^{* *}\right)$. $\mathrm{R}$ is the multiple correlation coefficients, between the observed and predicted values salary of the dependent variable employee performance. In the range of 0 to $1 \mathrm{r}$ value is significant.

Hypotheses 3: Correlation outcomes indicate that there was significant positive relationship between job involvement and employee performance $\left(\operatorname{sig}=.000 \mathrm{r}=.834^{* *}\right)$. $\mathrm{R}$ is the multiple correlation coefficients, between the observed and predicted values job involvement of the dependent variable employee performance. In the range of 0 to $1 \mathrm{r}$ value is significant.

$.889^{* *}$

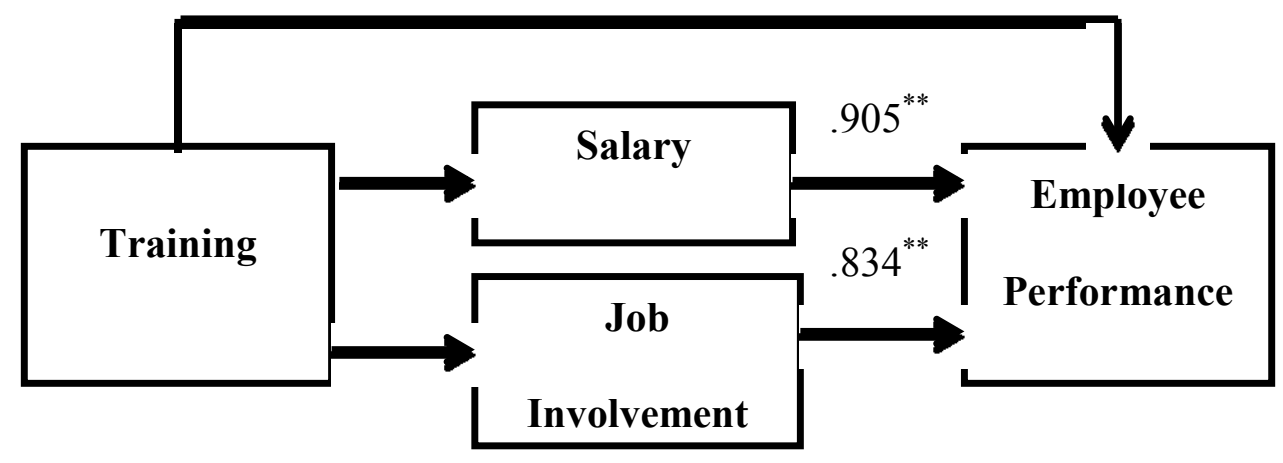

Figure 2. Relationship among variables and $\mathrm{r}$ values. 


\section{CONCLUSION}

In this research the impact of the training on the employee performance is studied. It further postulates that the managerial performance is meaningfully resolute through the training instructed to the personnel or in the other arguments training is a significant predecessor of the performance.

Performance of the association depends on the worker obligation which is to be determined by HR procedure of the training and organizational development. By presenting additional training platforms in the association workforces become involved to acquire further information about their employments which finally supports them in attainment of campaigns between their peer assemblies.

Though, there are additional features which lead to the performance between others, contain working situation, worker abilities and awareness, inspiration and prizes, communication stream and executive organization.

\section{FUTURE RESEARCH DIRECTIONS}

Though, we have recommended a comprehensive theoretic frame afterwards a cautious examination of writings and a complete reasonable rationalism; aimed at the situation better accuracy, rationality and the generalizability, forthcoming researchers are intensely stimulated to empirically assessment the advanced model in diverse executive situations/frameworks.

Future researchers concerned in the region should furthermore research into additional variables which correspondingly donate to the performance which the existing research cannot conceal.

\section{References}

[1] Aguinis H., Kraiger K., Annual review of psychology 60 (2009) 451-474.

[2] K. e. (1992). Management Made Easy, ( 1st ed. ed.). South Carolina: Omron Publishers

[3] Arrowsmith J., Sisson K., Marginson P., Journal of European Public Policy 11(2) (2004) 311-328.

[4] Blau G. J., Boal K. B., Academy of Management Review (1987) 288-300.

[5] Borman W. C., Motowidlo S. J., Human performance 10(2) (1997) 99-109.

[6] Brown S. P., Psychological bulletin 120(2) (1996) 235.

[7] Brown S. P., Leigh T. W., Journal of applied psychology 81(4) (1996) 358.

[8] Carrell M. R., Elbert N. F., Hatfield R. D. (1995). Human resource management: global strategies for managing a diverse workforce: Prentice Hall.

[9] Chopra M., Munro S., Lavis J. N., Vist G., Bennett S., The Lancet 371(9613) (2008) 668-674.

[10] Cron W. L., The Journal of Marketing (1984) 41-52. 
[11] DeSimone R. L., Werner J. M., Harris D. M. (2002). Human resource development: Thomson Learning, Inc.

[12] Dirks K. T., Ferrin D. L., Journal of applied psychology 87(4) (2002) 611.

[13] Dubinsky A. J., Hartley S. W., Journal of the Academy of Marketing Science 14(1) (1986) 36-46.

[14] Garavan T. N., Industrial and Commercial Training 29(3) (1997) 70-77.

[15] Harzing A.-W., Van Ruysseveldt J. (2004). International human resource management: Sage.

[16] Hersey P., Blanchard K. H. (1969). Management of organizational behavior: Prentice-Hall Englewood Cliffs, NJ.

[17] Israr S. M., Razum O., Ndiforchu V., Martiny P., Tropical Medicine \& International Health 5(4) (2000) 288-292.

[18] Kagaari Munene, et al., International Journal of Educational Management 24 (6) (2010) 507-530.

[19] Kanungo R. N., Journal of applied psychology 67(3) (1982) 341.

[20] Kelton W. D., Law A. M. (2000). Simulation modeling and analysis: McGraw Hill Boston, MA.

[21] Kober K., Van Damme W., Human Resources for Health 4(1) (2006) 13.

[22] Kyaddondo D., Whyte S. R., The International journal of health planning and management 18(4) (2003) 329-342.

[23] McGhee. (1996). Nature of Learning (1st ed ed.). Boston: McGraw-Hill Book Company.

[24] McPake B., et al., Social Science \& Medicine 49(7) (1999) 849-865.

[25] Munene J. C., Applied psychology 44(2) (1995) 111-122.

[26] Noe R. A., Hollenbeck J. R., Gerhart B., Wright P. M. (2004). Fundamentals of human resource management (Vol. 2): McGraw-Hill.

[27] Oshagbemi T., International Journal of Educational Management 14(1) (2000) 31-39.

[28] Pfeffer J. (1998). Seven practices of successful organizations. Org Dev \& Trng, 6E (Iae), 460.

[29] Roos G., Pike S., Fernstrom L. (2012). Managing intellectual capital in practice: Routledge.

[30] Sims D. (2001). Creative new employee orientation programs: Best practices, creative ideas, and activities for energizing your orientation program: McGraw Hill Professional. 
[31] Tanga P. T., Mbuagbo T. O., Fru C. N., Area 34(3) (2002) 325-328.

[32] Yip W. C.-M., Hsiao W., Meng Q., Chen W., Sun, X., The Lancet 375(9720) (2010) $1120-1130$.

[33] Youndt M. A., Snell S. A., Dean J. W., Lepak D. P., Academy of management Journal 39(4) (1996) 836-866.

[34] Zheng C., Journal of service management 20(5) (2009) 482-502. 